\title{
Selective Hydrogenation of Dodecanoic Acid to Dodecane-1-ol Catalyzed by Supported Bimetallic Ni-Sn Alloy
}

\author{
R. Rodiansono ${ }^{1, *}$, Muhammad Iqbal Pratama ${ }^{1}$, Maria Dewi Astuti ${ }^{1}$, A. Abdullah ${ }^{1}$, \\ Agung Nugroho' ${ }^{2}$ S. Susi ${ }^{2}$
}

${ }^{1}$ Department of Chemistry, Faculty of Mathematics and Natural Sciences, Lambung Mangkurat University, Jl. A. Yani Km 36.0 Banjarbaru South Kalimantan, Indonesia.

${ }^{2}$ Department of Agro-industrial Engineering, Faculty of Agriculture, Lambung Mangkurat University, Jl. A. Yani Km 36.0 Banjarbaru South Kalimantan, Indonesia

Received: $26^{\text {th }}$ November 2017; Revised: $24^{\text {nd }}$ December 2017; Accepted: $24^{\text {th }}$ January 2018; Available online: $11^{\text {st }}$ June 2018; Published regularly: $1^{\text {st }}$ August 2018

\section{Abstract}

Selective hydrogenation of dodecanoic acid over supported bimetallic Ni-Sn alloy catalysts into dodecane-1-ol is demonstrated. Bimetallic nickel-tin supported on titanium oxide $\left(\mathrm{Ni}-\mathrm{Sn}(1.5) / \mathrm{TiO}_{2}\right)$ and gamma-alumina $\left(\mathrm{Ni}-\mathrm{Sn}(1.5) / \gamma-\mathrm{Al}_{2} \mathrm{O}_{3}\right) ; 1.5=\mathrm{Ni} / \mathrm{Sn}$ molar ratio) were synthesized via hydrothermal method in a sealed-Teflon autoclave reactor at $150{ }^{\circ} \mathrm{C}$ for $24 \mathrm{~h}$, then followed by reducing with hydrogen gas at $400{ }^{\circ} \mathrm{C}$ for $1.5 \mathrm{~h}$. The synthesized catalysts were characterized by means of XRD, IC-AES, $\mathrm{N}_{2}$-adsorption (BET method), $\mathrm{H}_{2}$-chemisorption, and $\mathrm{NH}_{3}$-TPD. Bimetallic $\mathrm{Ni}$ - $\mathrm{Sn}(1.5) / \mathrm{TiO}_{2}$ catalyst was found to be effective for hydrogenation of dodecanoic acid (>99 \% conversion) to dodecane-1-ol (93\% yield) at $160{ }^{\circ} \mathrm{C}, 30$ bar $\mathrm{H}_{2}$, and $20 \mathrm{~h}$ and the highest dodecane-1-ol (97\% yield) was obtained at initial pressure of $\mathrm{H}_{2}$, 50 bar. An increase of reaction temperature slightly enhanced the degree of hydrodeoxygenation of dodecanoic acid to produce dodecane over both $\mathrm{Ni}-\mathrm{Sn}(1.5) / \mathrm{TiO}_{2}$ and $\mathrm{Ni}-\mathrm{Sn}(1.5) / \gamma-\mathrm{Al}_{2} \mathrm{O}_{3}$ catalysts. Copyright (C) 2018 BCREC Group. All rights reserved

Keywords: Bimetallic Nickel-Tin Alloy Catalyst; Dodecane; Dodecanoic Acid; Dodecane-1-ol; Hydrogenation

How to Cite: Rodiansono, R. Pratama, M.I., Astuti, M.D., Abdullah, A., Nugroho, A., Susi, S. (2018). Selective Hydrogenation of Dodecanoic Acid to Dodecane-1-ol Catalyzed by Supported Bimetallic Ni-Sn Alloy. Bulletin of Chemical Reaction Engineering \& Catalysis, 13 (2): 311-319

(doi:10.9767/bcrec.13.2.1790.311-319)

Permalink/DOI: https://doi.org/10.9767/bcrec.13.2.1790.311-319

\section{Introduction}

The development of oleochemical products including surfactants, lubricants, plasticizers, coatings, and polymers has been made possible by remarkable advances made in organic syn-

* Corresponding Author.

E-mail: rodiansono@ulm.ac.id (R. Rodiansono)

Telp: +62-5114773112, Fax: +62-5114782899 thesis, catalysis, and biotechnology [1]. Fatty alcohol is one of the important basic oleochemicals which could be produced by hydrogenation of fatty acids or its esters by using heterogeneous catalysts (e.g. bimetallic copper chromite), but the reaction requires harsh temperature (e.g., up to $300^{\circ} \mathrm{C}$ ) and pressure (e.g., up to 300 bar of $\mathrm{H}_{2}$ ) in the presence of copper-chromite catalysts, which are potentially harmful for the environ- 
ment $[2,3]$. In this regard, the development of catalysts to produce fatty alcohols under milder conditions has been long-standing industrial target.

Many previous attempts on the reduction of

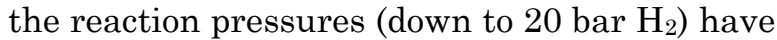
been achieved with high conversion and selectivities by replacing $\mathrm{Cu}$ or $\mathrm{Cr}$ with noble metals such as Ru, Rh, Re, Pd, or Pt [4]. For example, the hydrogenation of carboxylic acids to alcohols using a $\mathrm{Pt} / \mathrm{TiO}_{2}$ catalyst as reported recently by Hardacre et al. at only $130^{\circ} \mathrm{C}, 20$ bar $\mathrm{H}_{2}$ and gave over $80 \%$ conversion (with $90 \%$ selectivity) after $12 \mathrm{~h}$ [5]. Although these results are remarkable, it would be desirable to replace the expensive noble metals with more abundant and economic catalysts still capable of working at low $\mathrm{H}_{2}$ pressures and moderate reaction temperatures. The commercial Nibased catalysts such as: RANEY Ni/Kieselgur, or $\mathrm{Ni} / \mathrm{Al}_{2} \mathrm{O}_{3}$ had been applied for fatty acids or fatty ester hydrogenation with high activity. However, the important drawbacks of these catalysts are low selectivity to desired products (i.e., produced the mixture of cis- and transproduct) and easily deactivated due to carbon deposited on the metal surface [6].

Interactions between metals in bimetallic catalysts can modify their surfaces, which can be beneficial for the conversion and upgrading of highly complex biomass derived compounds [7-9]. In previously published studies, several bimetallic alloy transition metal catalysts (e.g. $\mathrm{Pd}-\mathrm{M}(\mathrm{M}=\mathrm{Cu}, \mathrm{Co}, \mathrm{Ni})$ [10], $\mathrm{Pd}-\mathrm{Nb}_{2} \mathrm{O}_{5}$ [11], $\mathrm{Ru}-$ Sn [12] Rh-Sn [13], and Ru-Ge-B [14] have shown superior performance for the selective hydrogenation of fatty acids compared with their single metal counterpart. Huang et al. [10] reported the catalytic performances of supported bimetallic $\mathrm{Pd}-\mathrm{M}(\mathrm{M}=\mathrm{Cu}, \mathrm{Co}, \mathrm{Ni})$ catalysts in hydrogenation of methyl palmitic in $\mathrm{n}$ heptane solvent at $270{ }^{\circ} \mathrm{C}, \mathrm{H}_{2} 55$ bar within $7 \mathrm{~h}$. Among these bimetallic catalysts, $\mathrm{Pd}$ $\mathrm{Cu}$ /diatomite with loading amount of $1 \%$ $(\mathrm{Pd} / \mathrm{Cu}=3)$ displayed the highest catalytic performances in hydrogenation of palmitic acid (99 $\%$ conversion) giving 1 -hexadecanol (83\% yield) [10]. On the other hand, by using $\mathrm{Pd} / \mathrm{Nb}_{2} \mathrm{O}_{5} / \mathrm{SiO}_{2}$ catalyst, a significant improvement of 1-hexadecanol yield was achieved (c.a. $97 \%$ yield) from palmitic acid in cyclohexane at $180{ }^{\circ} \mathrm{C}, \mathrm{H}_{2} 25$ bar, within $24 \mathrm{~h}$ of reaction time [11].

In previous reports, bimetallic Ru-based catalysts have also demonstrated high activity in hydrogenation of methyl oleate at relatively high temperature and $\mathrm{H}_{2}$ pressure (ca. $270{ }^{\circ} \mathrm{C}$ and 44 bar, respectively) within 7 h. However, the conversion of methyl oleate and selectivity of oleyl alcohol were only $80 \%$ and $70 \%$, respectively. The addition of electropositive atom of $\mathrm{Sn}$ and $\mathrm{B}$ to $\mathrm{Ru}$ enhanced the dispersion of $\mathrm{Ru}$ and improved the electron density of $\mathrm{Ru}$. The change of electron density $\mathrm{Ru}$ enhanced the affinity of $\mathrm{Ru}$ towards $\mathrm{C}=\mathrm{O}$ bond of fatty acids which facilitated the reaction hydrogenation [12,13]. Similar results have been also reported on the hydrogenation of dodecanoic acid and palmitic acid at $300{ }^{\circ} \mathrm{C}, 60$ bar $\mathrm{H}_{2}$, within 4 $\mathrm{h}$ over $\mathrm{Ru}-\mathrm{Sn} / \mathrm{Al}_{2} \mathrm{O}_{3}$ and $\mathrm{Rh}-\mathrm{Sn} / \mathrm{Al}_{2} \mathrm{O}_{3}$ catalysts and produced lauryl alcohol and hexadecane-1ol, respectively. On the other hand, Ru-Ge$\mathrm{B} / \mathrm{Al}_{2} \mathrm{O}_{3}$ catalyst gave only $20 \%$ of oleyl alcohol with conversion of methyl oleic, ca. $80 \%$ [14].

In our previous investigations, we have reported the synthesis of both bulk and supported bimetallic Ni-Sn alloy catalysts from two types nickel precursors: first, from nickel salt (e.g. $\mathrm{NiCl}_{2}$ or $\mathrm{NiCl}_{2} \cdot 4 \mathrm{H}_{2} \mathrm{O}$ ) produced from both bulk and supported Ni-Sn alloys [15] and, second, from Raney Ni-supported on aluminium hydroxide (R-Ni/AlOH), which produced a nickel-tin alloy supported on aluminium hydroxide (Ni-Sn $(x) / \mathrm{AlOH} ; x=\mathrm{Ni} / \mathrm{Sn}$ molar ratio) [16]. We have also recently reported the catalytic performance of the Ni-Sn alloy during hydrogenation of biomass-derived levulinic acid in water to $\gamma$-valerolactone (GVL) [17]. Over bulk Ni-Sn alloy catalysts, a relatively high reaction temperature $\left(150^{\circ} \mathrm{C}, 40\right.$ bar $\left.\mathrm{H}_{2}, 6 \mathrm{~h}\right)$ was applied to achieve both a high conversion and GVL yield (99 \%) [18]. Alternatively, a GVL yield of $>99 \%$ was obtained over $\mathrm{Ni}$ $\mathrm{Sn}(x) / \mathrm{AlOH}$ catalysts at a lower reaction temperature $\left(120^{\circ} \mathrm{C}\right)$ compared to the bulk catalysts [19].

In this present report, we continue our extend investigation of the hydrogenation of dodecanoic acid over supported bimetallic Ni-Sn alloy catalysts to the corresponding of lauryl alcohol. Bimetallic Ni-Sn alloy was supported on two types of supports c.a. titanium oxide $\left(\mathrm{TiO}_{2}\right)$ and gamma-alumina $\left(\gamma-\mathrm{Al}_{2} \mathrm{O}_{3}\right)$. Monometallic nickel supported on $\mathrm{TiO}_{2}\left(\mathrm{Ni} / \mathrm{TiO}_{2}\right)$ and $\gamma-\mathrm{Al}_{2} \mathrm{O}_{3}\left(\mathrm{Ni} /\left(\gamma-\mathrm{Al}_{2} \mathrm{O}_{3}\right)\right.$ catalysts were also evaluate for comparison.

\section{Materials and Methods}

\subsection{Materials}

Sodium hydroxide (NaOH) (97\%), nickel(II) chloride hexahydrate $\left(\mathrm{NiCl}_{2} .6 \mathrm{H}_{2} \mathrm{O}, 99.9 \%\right)$, tin(II) chloride dihydrate $\left(\mathrm{SnCl}_{2} \cdot 2 \mathrm{H}_{2} \mathrm{O}, 99.9 \%\right.$,), aluminium hydroxide, and $\mathrm{TiO}_{2}$ (mixture of rutile and anatase; $S_{\mathrm{BET}}=50 \mathrm{~m}^{2} \mathrm{~g}^{-1}$ ) were pur- 
chased and used as received from WAKO Pure Chemical Industries, Ltd. unless otherwise stated. The $\gamma-\mathrm{Al}_{2} \mathrm{O}_{3}\left(S_{\mathrm{BET}}=100 \mathrm{~m}^{2} \mathrm{~g}^{-1}\right)$ were purchased from Japan Aerosil Co. All organic chemical compounds were purified using standard procedures prior to use.

\subsection{Catalyst preparation}

\subsubsection{Synthesis of $\mathrm{Ni}-\mathrm{Sn}(1.5) / \mathrm{TiO}_{2}$}

A typical procedure of the synthesis of titanium oxide supported $\mathrm{Ni}-\mathrm{Sn}$ (1.5 is feeding ratio) alloy catalyst is described as follows [15]: $\mathrm{NiCl}_{2} \cdot 6 \mathrm{H}_{2} \mathrm{O}(7.2 \mathrm{mmol})$ was dissolved in deionized water (denoted as solution $\mathrm{A}$ ), and $\mathrm{SnCl}_{2} \cdot 2 \mathrm{H}_{2} \mathrm{O}(4.8 \mathrm{mmol})$ was dissolved in ethanol/2-methoxy ethanol (2:1) (denoted as solution $\mathrm{B})$ at room temperature. A one-gram titanium oxide $\left(\mathrm{TiO}_{2}\right)$, solutions $\mathrm{A}$, and $\mathrm{B}$ were mixed at room temperature; the temperature was subsequently raised to $50{ }^{\circ} \mathrm{C}$ and the mixture was stirred for $12 \mathrm{~h}$. The $\mathrm{pH}$ of the mixture was adjusted to 12 through the dropwise addition of an aqueous solution of $\mathrm{NaOH}$ (3.1 $\mathrm{M})$. The mixture was then placed into a sealedTeflon autoclave for the hydrothermal reaction at $150{ }^{\circ} \mathrm{C}$ for $24 \mathrm{~h}$. The resulting black precipitate was filtered, washed with distilled water, and then dried under vacuum overnight. Prior to the catalytic reaction, the obtained black powder was treated under hydrogen at $400{ }^{\circ} \mathrm{C}$ for $1.5 \mathrm{~h}$.

\subsubsection{Catalyst characterization}

Powder X-ray diffraction (XRD) measurements were recorded on a Mac Science M18XHF instrument using monochromatic CuKa radiation $(l=0.15418 \mathrm{~nm})$. The XRD was operated at $40 \mathrm{kV}$ and $200 \mathrm{~mA}$ with a step width of $0.02^{\circ}$ and a scan speed of $4^{\circ} \mathrm{min}^{-1}(\mathrm{a} 1=$ $0.154057 \mathrm{~nm}, \alpha 2=0.154433 \mathrm{~nm})$. Inductively coupled plasma-atomic emission spectroscopy (ICP-AES) measurements were performed on an SPS $1800 \mathrm{H}$ plasma spectrometer by Seiko Instruments Inc. Japan (Ni: $221.7162 \mathrm{~nm}$ and Sn: $189.898 \mathrm{~nm})$. The Brunauer-Emmett-Teller surface area $\left(S_{\text {ВET }}\right)$ and pore volume $\left(V_{p}\right)$ were measured using $\mathrm{N}_{2}$ physisorption at $-196{ }^{\circ} \mathrm{C}$ on a Belsorp Max (BEL Japan). The samples were degassed at $200{ }^{\circ} \mathrm{C}$ for $2 \mathrm{~h}$ to remove physisorbed gases prior to the measurement. The amount of nitrogen adsorbed onto the samples was used to calculate the BET surface area via the BET equation. The pore volume was estimated to be the liquid volume of nitrogen at a relative pressure of approximately 0.995 ac- cording to the Barrett-Joyner-Halenda (BJH) approach based on desorption data [20].

The $\mathrm{H}_{2}$ uptake was determined through irreversible $\mathrm{H}_{2}$ chemisorption. After the catalyst was heated at $100{ }^{\circ} \mathrm{C}$ under vacuum for $30 \mathrm{~min}$, it was then heated at $400{ }^{\circ} \mathrm{C}$ under $\mathrm{H}_{2}$ for 30 $\min$. The catalysts were subsequently cooled to room temperature under vacuum for $30 \mathrm{~min}$. The $\mathrm{H}_{2}$ measurement was conducted at $0{ }^{\circ} \mathrm{C}$, and the $\mathrm{H}_{2}$ uptake was calculated according to a method described in the literature [21,22].

The $\mathrm{NH}_{3}$-TPD was carried out on a Belsorp Max (BEL Japan). The samples were degassed at elevated temperature of $100-200{ }^{\circ} \mathrm{C}$ for $2 \mathrm{~h}$ to remove physisorbed gases prior to the measurement. The temperature was then kept at $200{ }^{\circ} \mathrm{C}$ for $2 \mathrm{~h}$ while flushed with $\mathrm{He}$ gas. $\mathrm{NH}_{3}$ gas (balanced $\mathrm{NH}_{3}, 80 \%$, and $\mathrm{He}, 20 \%$ ) was introduced at $100{ }^{\circ} \mathrm{C}$ for $30 \mathrm{~min}$, then evacuated by helium gas to remove the physisorbed also for $30 \mathrm{~min}$. Finally, temperature programmed desorption was carried out at temperature of $100-800{ }^{\circ} \mathrm{C}$ and the desorbed $\mathrm{NH}_{3}$ was monitored by TCD.

\subsection{Catalytic reaction}

Typical catalytic reaction procedure as follows. Catalyst (0.05 g), dodecanoic acid (1.8 $\mathrm{mmol}$ ), internal standar of 1,6-hexanediol (0.03 $\mathrm{mmol})$ and iso-PrOH $(5 \mathrm{~mL})$ as solvent were placed into a glass reaction tube, which fitted inside a stainless-steel reactor. The reactor was flushed with $\mathrm{H}_{2}$ for $\sim 30$ times. Finally, after $\mathrm{H}_{2}$ was introduced into the reactor with an initial $\mathrm{H}_{2}$ pressure of 30 bar at room temperature, the temperature of the reactor was increased to $160{ }^{\circ} \mathrm{C}$. After $6 \mathrm{~h}$ of the reaction, both heating and stirring were stopped, the autoclave was removed from the hot plate and then cooled in ice-cold water. Once cooled, the contents of the autoclave were transferred into sample bin then centrifuged ( 4000 rpm for $10 \mathrm{~min})$ and ready for GC-FID analysis. The Ni$\mathrm{Sn}(1.5) / \mathrm{TiO}_{2}$ catalyst was easily separated using either simple centrifugation $(4000 \mathrm{rpm}$ for $10 \mathrm{~min}$ ) or filtration, then finally dried overnight under vacuum at room temperature prior to re-usability testing.

\subsection{Product analysis}

Gas chromatography analysis of the reactant (dodecanoic acid) and products was performed on a Perkin Elmer Autosystem XL with a flame ionization detector with an InertCap 225 (i.d. $0.25 \mathrm{~mm}$, length $30 \mathrm{~m}$, d.f. $0.25 \mathrm{~mm}$ ) capillary column of GL Science Inc. Tokyo Ja- 
pan. The products were confirmed by a comparison of their GC retention time, mass spectra with those of authentic samples. Gas chromatography-mass spectrometry (GC-MS) was performed on a Shimadzu GC-17B equipped with a thermal conductivity detector and an RT- $\beta$ DEXsm capillary column.

The amount of remained reactant and products were determined from GC data using internal standard of 1,6-hexanediol that was introduced to the reactor before reaction run. Calibration curve was performed using known concentrations of internal standard, reactants and products in order to determine the correct response factors. The conversion of dodecanoic acid, yield, and selectivity of the products were calculated according to the following equations:

$$
\begin{aligned}
& \text { Conversion }=\frac{F_{0}-F_{t}}{F_{0}} \times 100 \% \\
& \text { Yield }=\frac{\text { mol product }}{F_{0}} \times 100 \%
\end{aligned}
$$

$$
\text { Selectivity }=\frac{\text { mol product }}{\text { total mol products }} \times 100 \%
$$

where $F_{0}$ is the introduced mol reactant (dodecanoic acid), $F_{t}$ is the remaining mol reactant, and $\Delta F$ is the consumed mol reactant (introduced mol reactant - remained mol reactant), which are all obtained from GC analysis using an internal standard technique.

\section{Results and Discussion}

\subsection{Catalyst characterization}

The chemical compositions, BET specific surface area $\left(S_{\text {BET }}\right)$, and total pore volume $\left(V_{\mathrm{p}}\right)$ for $\gamma-\mathrm{Al}_{2} \mathrm{O}_{3}$ or $\mathrm{TiO}_{2}$ supported $\mathrm{Ni}-\mathrm{Sn}(1.5)$ catalysts after $\mathrm{H}_{2}$ treatment at $400{ }^{\circ} \mathrm{C}$ for $1.5 \mathrm{~h}$ are summarized in Table 1. Based on the ICP-AES analyses, the compositions of the supported $\mathrm{Ni}$ Sn alloy were approximately equivalent to the feeding ratios of each precursor and were reflected in the composition of each Ni-Sn alloy phase. The total loading amount of Ni-Sn was 2.3 2.4 mmol.g-1 for all of the supported $\mathrm{Ni}$ $\mathrm{Sn}(1.5)$ samples (the composition (mol\%) of $\mathrm{Ni}$ and $\mathrm{Sn}$ are listed in Table 1). The $S_{\text {BET }}$ and total pore volume $\left(V_{\mathrm{p}}\right)$ of each supported $\mathrm{Ni}$ $\mathrm{Sn}(1.5)$ alloy samples were also summarized in Table 1. It is found that the $S_{\text {BET }}$ and $V_{\mathrm{p}}$ of Ni$\mathrm{Sn}(1.5) / \gamma-\mathrm{Al}_{2} \mathrm{O}_{3}$ were $94 \mathrm{~m}^{2} \mathrm{~g}^{-1}$ and $0.39 \mathrm{~cm}^{3} \mathrm{~g}^{-1}$, respectively (entry 1 ), while for $\mathrm{Ni}-\mathrm{Sn}(1.5) / \mathrm{TiO}_{2}$ were $52 \mathrm{~m}^{2} \mathrm{~g}^{-1}$ and $0.17 \mathrm{~cm}^{3} \mathrm{~g}^{-1}$ (entry 2). It can be observed that $S_{\text {BET }}$ and total pore volume of $\mathrm{TiO}_{2}$ supported catalyst lower than that of $\gamma$ $\mathrm{Al}_{2} \mathrm{O}_{3}$ supported catalysts. It was reported that metal species lead more dispersible on support with lower porosity (e.g. $\mathrm{TiO}_{2}$ ) due to strong interaction between metal and support which will prevent metal aggregation or sintering during thermal treatment $[15,23]$.

The $\mathrm{H}_{2}$ uptake for Ni-Sn(1.5)/TiO 2 and Ni$\mathrm{Sn}(1.5) / \gamma-\mathrm{Al}_{2} \mathrm{O}_{3}$ samples were 9.0 and 13.0 $\mu$ molg-1 ${ }^{-1}$ respectively and the average Ni-Sn alloy crystallite sizes derived from Scherrer equation of $\mathrm{Ni}_{3} \mathrm{Sn}_{2}$ (101) phase at $2 \theta=30.8^{\circ}$ were $16 \mathrm{~nm}$ and $6 \mathrm{~nm}$, respectively. The $\mathrm{H}_{2}$ uptake supported Ni-Sn alloy in this work was much lower than that of the Raney Ni or supported $\mathrm{Ni}$ on aluminium hydroxide, suggesting that the presence of second metal of Sn reduced significantly the accessibility of hydrogen on the surface of $\mathrm{Ni}$ metal. Consequently, the catalytic reaction may be effectively proceeded at high pressure of $\mathrm{H}_{2}$ as its have been reported previously [15-19],

The XRD patterns of Ni-Sn(1.5)/ $\gamma-\mathrm{Al}_{2} \mathrm{O}_{3}$ alloy catalyst after $\mathrm{H}_{2}$ treatment at $400{ }^{\circ} \mathrm{C}$ for 1.5 $\mathrm{h}$ are shown in Figure 1. It can be observed easily that $\mathrm{Ni}_{3} \mathrm{Sn}_{2}$ species as major alloy phase was formed on $\gamma-\mathrm{Al}_{2} \mathrm{O}_{3}$ with sharped peaks with very similar patterns to the JCPDS card standard of $\mathrm{Ni}_{3} \mathrm{Sn}_{2}$ of 6-414 [24]. On the other hand, the XRD patterns $\mathrm{Ni}-\mathrm{Sn}(1.5) / \mathrm{TiO}_{2}$ exhibited broadened peaks at $2 \theta=30.8^{\circ}, 42.5^{\circ}$, and $44.2^{\circ}$, which correspond to the $\mathrm{Ni}_{3} \mathrm{Sn}_{2}$ (101),

Table 1. Chemical composition, BET surface area $\left(S_{\mathrm{BET}}\right)$, and total pore volume $\left(V_{\mathrm{p}}\right)$ for Ni-Sn(1.5)/ $\gamma$ $\mathrm{Al}_{2} \mathrm{O}_{3}$ and $\mathrm{Ni}-\mathrm{Sn}(1.5) / \mathrm{TiO}_{2}$ catalysts after $\mathrm{H}_{2}$ treatment at $400{ }^{\circ} \mathrm{C}$ for $1.5 \mathrm{~h}$.

\begin{tabular}{clccc}
\hline Entry & \multicolumn{1}{c}{ Catalysta } & $\begin{array}{c}\text { Comp. } \\
\left(\mathrm{mol}^{\mathrm{b}}\right)\end{array}$ & $\begin{array}{c}S_{\mathrm{BET}^{\mathrm{c}}} \\
\left(\mathrm{m}^{2} \mathrm{~g}^{-1}\right)\end{array}$ & $\begin{array}{c}V_{\mathrm{p}^{\mathrm{c}}} \\
\left(\mathrm{cm}^{3} \mathrm{~g}^{-1}\right)\end{array}$ \\
\hline 1 & $\mathrm{Ni}-\mathrm{Sn}(1.5) / \gamma-\mathrm{Al}_{2} \mathrm{O}_{3}$ & $\mathrm{Ni}_{60.2} \mathrm{Sn}_{39.8}$ & 94 & 0.39 \\
2 & $\mathrm{Ni}-\mathrm{Sn}(1.5) / \mathrm{TiO}_{2}$ & $\mathrm{Ni}_{60.4} \mathrm{Sn}_{39.6}$ & 52 & 0.17 \\
\hline
\end{tabular}

aThe value between the parenthesis is Ni/Sn molar ratio. bMolar composition of Ni or Sn, determined by ICP-AES. cDetermined by $\mathrm{N}_{2}$ adsorption at $-196{ }^{\circ} \mathrm{C}$. The pore volume was estimated to be the liquid volume of nitrogen at a relative pressure of approximately 0.995 according to the Barrett-Joyner-Halenda (BJH) approach based on desorption data. 
$\mathrm{Ni}_{3} \mathrm{Sn}_{2}$ (102), and $\mathrm{Ni}_{3} \mathrm{Sn}_{2}$ (110) diffraction peaks, respectively (Figure 2). These results suggest that the higher dispersions of Ni-Sn alloy on the $\mathrm{TiO}_{2}$ were formed as roughly depicted in the average $\mathrm{Ni}_{3} \mathrm{Sn}_{2}$ (101) crystallite sizes, which were $6 \mathrm{~nm}$ (Table 2). In conclusion, the XRD analysis and $\mathrm{H}_{2}$ measurement results confirm that Ni-Sn alloy phases were also formed on the supports and that their characteristics were consistent with the results observed for the bulk material as reported previously [15].

The results of ammonia-temperature programmed desorption $\left(\mathrm{NH}_{3}\right.$-TPD) measurements of the synthesized catalysts are summarized in Table 3 and the $\mathrm{NH}_{3}$-TPD profiles are shown in Figure 3 and Figure 4. It can be observed that $\mathrm{Ni}-\mathrm{Sn}(1.5) / \gamma-\mathrm{Al}_{2} \mathrm{O}_{3}$ alloy catalyst consisted of three different peak positions of 178,510 , and

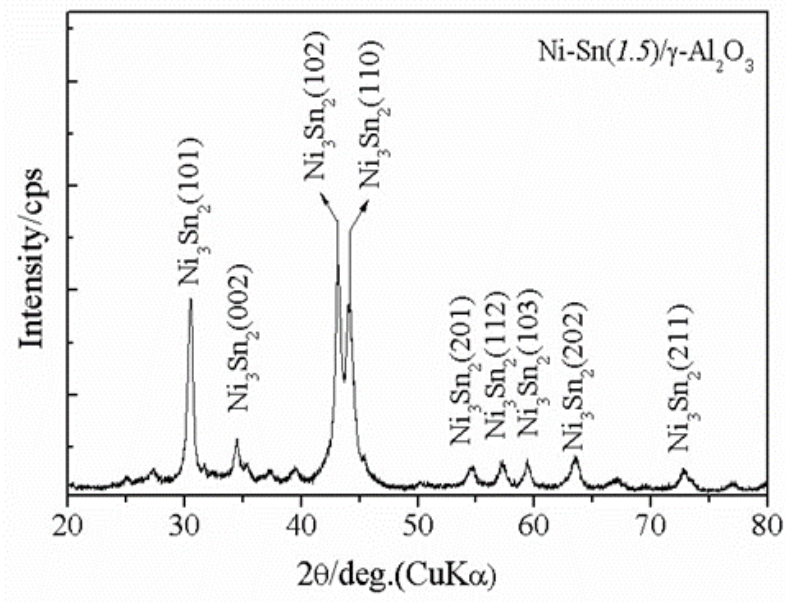

Figure 1. XRD patterns of bimetallic Ni-Sn (1.5) supported on g- $\mathrm{Al}_{2} \mathrm{O}_{3}$ after $\mathrm{H}_{2}$ treatment at $400{ }^{\circ} \mathrm{C}$ for $1.5 \mathrm{~h}$

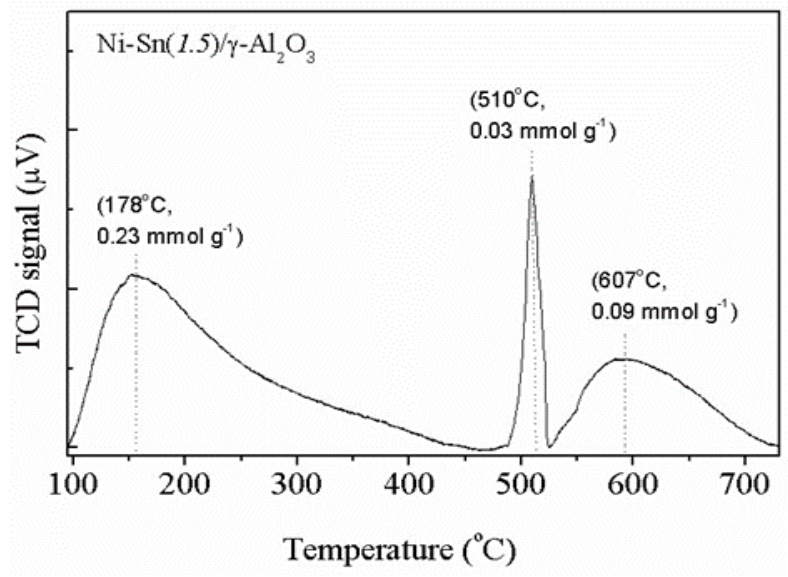

Figure 3. $\mathrm{NH}_{3}$-TPD spectra of $\mathrm{Ni}-\mathrm{Sn}(1.5) / \gamma$ $\mathrm{Al}_{2} \mathrm{O}_{3}$ catalyst after $\mathrm{H}_{2}$ treatment at $400{ }^{\circ} \mathrm{C}$ for $1.5 \mathrm{~h}$
$607{ }^{\circ} \mathrm{C}$ with acidic amount of $0.23,0.03$, and 0.09 mmol.g ${ }^{-1}$, respectively (Figure 3 and Table 3 , entry 1) with total number of acid sites $=$ $0.35 \mathrm{mmol} . \mathrm{g}^{-1}$. Therefore, it can be concluded that $\mathrm{Ni}-\mathrm{Sn}(1.5) / \gamma-\mathrm{Al}_{2} \mathrm{O}_{3}$ catalyst has mainly weak acid sites. On the other hand, Ni$\mathrm{Sn}(1.5) / \mathrm{TiO}_{2}$ displayed the peak position at 611 ${ }^{\circ} \mathrm{C}$ with total number of acidic sites $=0.29$ mmol.g- ${ }^{-1}$ that can be attributed to the strong acid sites (Figure 4 and Table 3, entry 2) [25, 26].

\subsection{Hydrogenation of dodecanoic acid}

\subsubsection{Screening of catalysts}

Results of selective hydrogenation of dodecanoic acid over supported bimetallic Ni$\operatorname{Sn}(1.5)$ catalysts are summarized in Table 4 and the reaction pathways are shown in

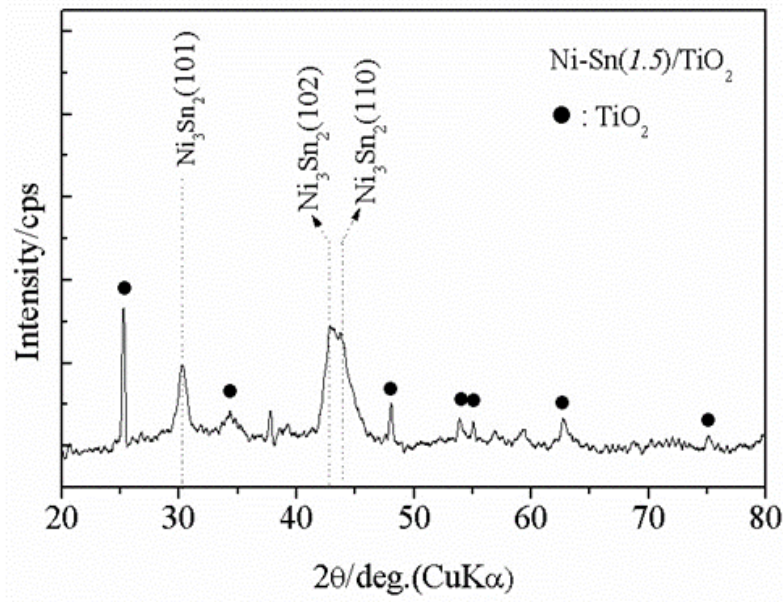

Figure 2. XRD patterns of bimetallic Ni$\mathrm{Sn}(1.5)$ alloy supported on $\mathrm{TiO}_{2}$ after $\mathrm{H}_{2}$ treatment at $400{ }^{\circ} \mathrm{C}$ for $1.5 \mathrm{~h}$

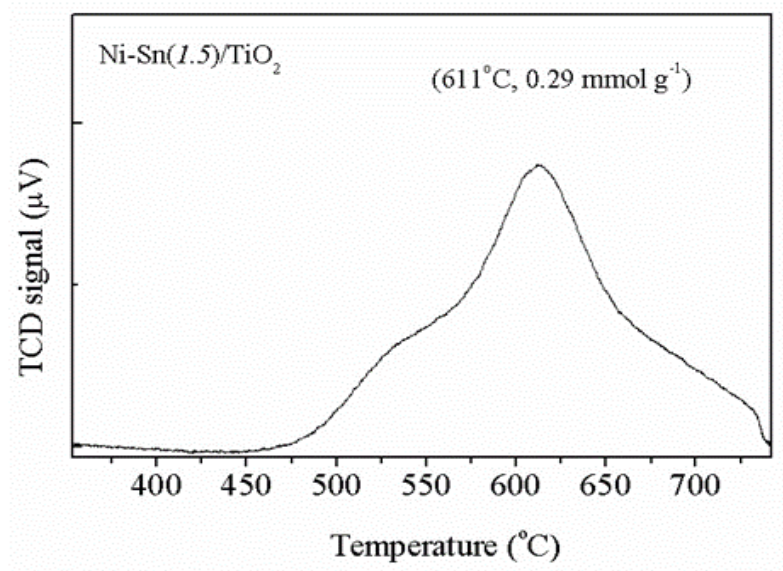

Figure 4. $\mathrm{NH}_{3}-\mathrm{TPD}$ spectra of $\mathrm{Ni}-\mathrm{Sn}(1.5) / \mathrm{TiO}_{2}$ catalyst after $\mathrm{H}_{2}$ treatment at $400{ }^{\circ} \mathrm{C}$ for $1.5 \mathrm{~h}$ 
Scheme 1. It can be observed that by using the $\mathrm{Ni}-\mathrm{Sn}(1.5) / \gamma-\mathrm{Al}_{2} \mathrm{O}_{3}$ catalysts, the conversion of dodecanoic acid was $59 \%$ with dodecane-1-ol yield was $40 \%$ while dodecane-1,1-diol and dodecane yields were $1 \%$ and $4 \%$, respectively (entry 1). The conversion of dodecanoic acid reached $89 \%$ when the reaction time was extended to $16 \mathrm{~h}$ and yielded $57 \%$ and $4 \%$ of dodecane-1-ol and dodecane, respectively (entry 2). Interestingly, $\mathrm{Ni}-\mathrm{Sn}(1.5) / \mathrm{TiO}_{2}$ catalyst displayed a high conversion of dodecanoic acid (c.a. $85 \%$ ) and high yield of dodecane-1-ol (c.a. $80 \%$ ) (entry 3). The yield of dodecane-1-ol increased significantly to $90 \%$ (with $97 \%$ conversion) without significant formation of byproduct when the reaction time was extended to $16 \mathrm{~h}$ (entry 4). It can be observed that $\mathrm{Ni}$ -

Table 2. $\mathrm{H}_{2}$ chemisorption and average crystallite sizes of $\mathrm{Ni}_{3} \mathrm{Sn}_{2}$ alloy phase for $\mathrm{Ni}-\mathrm{Sn}(1.5) / \gamma$ $\mathrm{Al}_{2} \mathrm{O}_{3}$ and $\mathrm{Ni}-\mathrm{Sn}(1.5) / \mathrm{TiO}_{2}$ catalysts after $\mathrm{H}_{2}$ treatment at $400{ }^{\circ} \mathrm{C}$ for $1.5 \mathrm{~h}$

\begin{tabular}{cccc}
\hline $\begin{array}{c}\text { En- } \\
\text { try }\end{array}$ & Catalysta $^{\mathrm{N}}$ & $\begin{array}{c}\mathrm{H}_{2} \text { uptake }^{\mathrm{b}} \\
\left(\mathrm{mmol} \mathrm{g}^{-1}\right)\end{array}$ & $D^{\mathrm{c}}(\mathrm{nm})$ \\
\hline 1 & $\mathrm{Ni}-\mathrm{Sn}(1.5) / \gamma-\mathrm{Al}_{2} \mathrm{O}_{3}$ & 9.1 & 16 \\
2 & $\mathrm{Ni}-\mathrm{Sn}(1.5) / \mathrm{TiO}_{2}$ & 13.0 & 6 \\
\hline
\end{tabular}

aThe value between the parenthesis is $\mathrm{Ni} / \mathrm{Sn}$ molar ratio. ${ }^{b}$ Based on total $\mathrm{H}_{2}$ uptake at $0{ }^{\circ} \mathrm{C}$ (noted after corrected for physical and chemical adsorption. cThe average crystallite sizes of $\mathrm{Ni}_{3} \mathrm{Sn}_{2}(101)$ alloy phase at $2 \theta=30.8^{\circ}$ was derived from Scherrer equation.
$\mathrm{Sn}(1.5) / \mathrm{TiO}_{2}$ catalyst showed higher catalytic performance than that of $\mathrm{Ni}-\mathrm{Sn}(1.5) / \gamma-\mathrm{Al}_{2} \mathrm{O}_{3}$. The high conversion of dodecanoic acid and the high yield of dodecan-1-ol over $\mathrm{Ni}-\mathrm{Sn}(1.5) / \mathrm{TiO}_{2}$ can be attributed to the relatively high dispersion of $\mathrm{Ni}-\mathrm{Sn}$ alloy on $\mathrm{TiO}_{2}$ giving rise to active sites with a significantly higher catalytic activity. Alternatively, the high conversion and selectivity may be a result of the strong interactions between the active metals and $\mathrm{TiO}_{2}$ generating significant interactions between $\mathrm{C}=\mathrm{O}$ groups and $\mathrm{Ni}^{-} \mathrm{TiO}_{\mathrm{x}}$ sites and leading to high selectivity to dodecane-1-ol [27].

The results of re-usability test confirmed that $\mathrm{Ni}-\mathrm{Sn}(1.5) / \mathrm{TiO}_{2}$ catalyst was re-usable and the activity and selectivity of the catalyst can be restored to the initial after reducing with $\mathrm{H}_{2}$

Table 3. $\mathrm{NH}_{3}-\mathrm{TPD}$ results for $\mathrm{Ni}-\mathrm{Sn}(1.5)$ alloy supported on $\gamma-\mathrm{Al}_{2} \mathrm{O}_{3}$ and $\mathrm{TiO}_{2}$ catalysts after $\mathrm{H}_{2}$ treatment at $400{ }^{\circ} \mathrm{C}$ for $1.5 \mathrm{~h}$

\begin{tabular}{|c|c|c|c|}
\hline \multirow[b]{2}{*}{$\begin{array}{l}\text { En- } \\
\text { try }\end{array}$} & \multirow[b]{2}{*}{ Catalysta } & \multicolumn{2}{|c|}{$\mathrm{NH}_{3}-\mathrm{TPD}$ data $^{\mathrm{b}}$} \\
\hline & & $\begin{array}{l}\text { Peak postion } \\
\left({ }^{\circ} \mathrm{C}\right)\end{array}$ & $\begin{array}{c}\text { Acidic } \\
\text { amount }^{\mathrm{c}} \\
\left.(\mathrm{mmol.g})^{-1}\right)\end{array}$ \\
\hline \multirow[t]{3}{*}{1} & $\mathrm{Ni}-\mathrm{Sn}(1.5) / \gamma-\mathrm{Al}_{2} \mathrm{O}_{3}$ & 178 (weak) & 0.23 \\
\hline & & 510 (medium) & 0.03 \\
\hline & & 607 (strong) & 0.09 \\
\hline 2 & $\mathrm{Ni}-\mathrm{Sn}(1.5) / \mathrm{TiO}_{2}$ & 611 (strong) & 0.29 \\
\hline
\end{tabular}

aThe value in the parenthesis is $\mathrm{Ni} / \mathrm{Sn}$ molar ratio. ${ }^{\mathrm{b}} \mathrm{Ammo-}$ nia-temperature programmed desorption ( $\mathrm{NH}_{3}$-TPD). ${ }^{\mathrm{c}}$ Acidic amount (mmol.g- ${ }^{-1}$ ) was derived from $\mathrm{NH}_{3}$-TPD spectra.

Table 4. Results of dodecanoic acid hydrogenation/hydrodeoxygenation over supported Ni-based catalysts

\begin{tabular}{|c|c|c|c|c|c|c|c|}
\hline \multirow{2}{*}{ Entry } & \multirow{2}{*}{ Catalysta } & \multirow{2}{*}{ 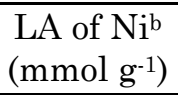 } & \multirow{2}{*}{ Conversion ${ }^{\mathrm{c}}(\%)$} & \multicolumn{4}{|c|}{ Yieldc(\%) } \\
\hline & & & & $(1)$ & $(2)$ & (3) & Others $^{\mathrm{d}}$ \\
\hline 1 & $\mathrm{Ni}-\mathrm{Sn}(1.5) / \gamma-\mathrm{Al}_{2} \mathrm{O}_{3}$ & 2.4 & 59 & 40 & 1 & 4 & 14 \\
\hline $2^{\mathrm{e}}$ & $\mathrm{Ni}-\mathrm{Sn}(1.5) / \gamma-\mathrm{Al}_{2} \mathrm{O}_{3}$ & 2.4 & 89 & 57 & 0 & 4 & 28 \\
\hline 3 & $\mathrm{Ni}-\mathrm{Sn}(1.5) / \mathrm{TiO}_{2}$ & 2.5 & 85 & 80 & 0 & 3 & 2 \\
\hline $4^{e}$ & $\mathrm{Ni}-\mathrm{Sn}(1.5) / \mathrm{TiO}_{2}$ & 2.5 & 97 & 90 & 0 & 6 & 1 \\
\hline $5^{f}$ & $\mathrm{Ni}-\mathrm{Sn}(1.5) / \mathrm{TiO}_{2}$ & 2.5 & 85 & 83 & 0 & 1 & 1 \\
\hline $6 \mathrm{~g}$ & $\mathrm{Ni}-\mathrm{Sn}(1.5) / \mathrm{TiO}_{2}$ & 2.5 & 11 & 0 & 0 & 0 & 10 \\
\hline 7 & $\mathrm{Ni} / \gamma-\mathrm{Al}_{2} \mathrm{O}_{3}$ & 2.7 & 55 & 23 & 0 & 7 & 25 \\
\hline 8 & $\mathrm{Ni} / \mathrm{TiO}_{2}$ & 2.6 & 41 & 39 & 0 & 2 & 0 \\
\hline 9 & $\mathrm{Sn} / \gamma-\mathrm{Al}_{2} \mathrm{O}_{3}$ & 3.7 & 0 & 0 & 0 & 0 & 0 \\
\hline $10^{\mathrm{h}}$ & $\mathrm{Ni}-\mathrm{Sn}(1.5) / \gamma-\mathrm{Al}_{2} \mathrm{O}_{3}$ & 2.4 & $>99$ & 85 & 0 & 9 & 6 \\
\hline
\end{tabular}

Reaction conditions: Catalyst, $0.065 \mathrm{~g}$; dodecanoic acid, $3.2 \mathrm{mmol}$; iso- $\mathrm{PrOH}, 5 \mathrm{~mL}, 160{ }^{\circ} \mathrm{C} ; \mathrm{H}_{2}$ pressure 30 bar, reaction time is 6

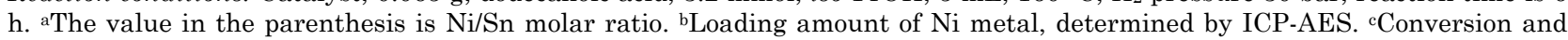
selectivity of the main products were determined by GC using an internal standard technique. Product (1) = dodecane-1-ol, (2) dodecane-1,1-diol, and (3) dodecane. dOther products were mainly $\mathrm{C}_{11}$ hydrocarbon including undecane $\left(\mathrm{C}_{11} \mathrm{H}_{24}\right)$, undecene $\left(\mathrm{C}_{11} \mathrm{H}_{22}\right)$, and trace amount of cracking product like 1-pentylbenzene was identified by using GC-MS analysis. eReaction time was

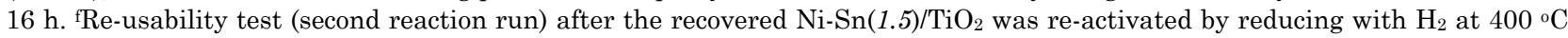

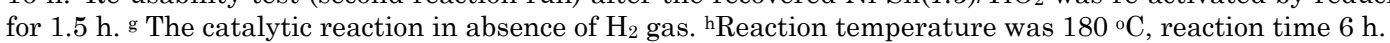


(85\% conversion and $83 \%$ yield, entry 5). Catalytic reaction over $\mathrm{Ni}-\mathrm{Sn}(1.5) / \mathrm{TiO}_{2}$ catalyst in absence of $\mathrm{H}_{2}$ gas gave dodecanoic acid conversion of $11 \%$ without the formation of hydrogenated products (entry 6). Compared to the supported bimetallic catalysts, monometallic $\mathrm{Ni} / \gamma-\mathrm{Al}_{2} \mathrm{O}_{3}$ and $\mathrm{Ni} / \mathrm{TiO}_{2}$ catalysts exhibited lower activity under the same reaction conditions (entries 7 and 8). Moreover, $\mathrm{Sn} / \mathrm{AlOH}$ was not active as catalysts and did not produce the hydrogenated products under the same conditions (entry 9). In addition, $\mathrm{Ni}-\mathrm{Sn}(1.5) / \gamma-\mathrm{Al}_{2} \mathrm{O}_{3}$ catalyst produced dodecane-1-ol (85\%), dodecane $(9 \%)$, and other products $(6 \%)$ when the reaction temperature was $180{ }^{\circ} \mathrm{C}$ within $6 \mathrm{~h}$ (entry 10).

\subsubsection{Profile of reaction kinetics}

Kinetics of the hydrogenation of dodecanoic acid over bimetallic $\mathrm{Ni}-\mathrm{Sn}(1.5) / \mathrm{TiO}_{2}$ and $\mathrm{Ni}$ $\mathrm{Sn}(1.5) / \gamma-\mathrm{Al}_{2} \mathrm{O}_{3}$ catalysts are shown in Figure 5. When Ni-Sn(1.5) $/ \gamma-\mathrm{Al}_{2} \mathrm{O}_{3}$ catalyst was used, dodecanoic acid was slowly increased at the initial reaction time to achieve a $93 \%$ yield after $24 \mathrm{~h}$. Therefore, a similar explanation can be applied to the current results as follows. The induction periods could be associated with the slow formation of oxidic tin $\left(\mathrm{Sn}^{\mathrm{n}}\right)$ from metallic tin $\left(\mathrm{Sn}^{0}\right)$, as reported by Sordelli et al. (Rh-Sn) [28] and Margitfalvi et al. (Pt-Sn) [29]. Since the crystallite size or dispersion of Ni-Sn alloy could affect the length of the induction period, the induction period of $\mathrm{Ni}-\mathrm{Sn}(1.5) / \mathrm{TiO}_{2}$ diminished, and a $100 \%$ dodecanoic acid conversion ( $90 \%$ dodecane-1-ol yield) was achieved after $20 \mathrm{~h}$. The excellent catalytic performance of $\mathrm{Ni}$ $\mathrm{Sn}(1.5) / \mathrm{TiO}_{2}$ produces a promising candidate suitable for the large-scale production of dodecane-1-ol from the selective hydrogenation of dodecanoic acid.

\subsubsection{Effect of reaction temperature}

The effect of reaction temperature on the catalytic performance of $\mathrm{Ni}-\mathrm{Sn}(1.5) / \mathrm{TiO}_{2}$ in do-

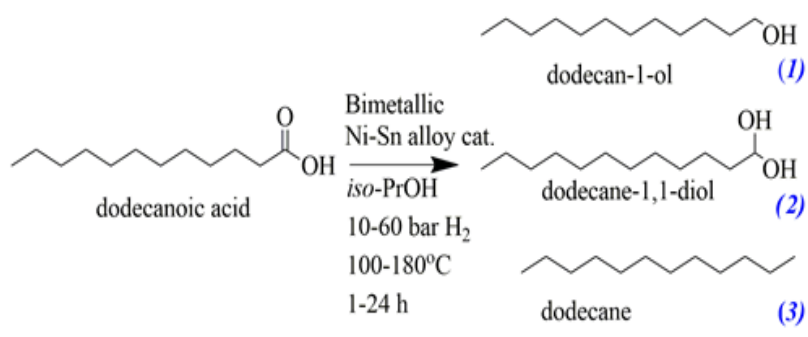

Scheme 1. Hydrogenation of dodecanoic acid over supported bimetallic $\mathrm{Ni}-\mathrm{Sn}(1.5)$ alloy catalysts. decanoic acid hydrogenation are also investigated and the results are shown in Figure 6 . The conversion of dodecanoic acid gradually increased as the increase of reaction temperature and reached to completed reaction at $180{ }^{\circ} \mathrm{C}$ within $6 \mathrm{~h}$ with dodecane-1-ol yield of $91 \%$ (entry 4). A small amount of dodecane (4\% yield) and other products (total yield of $12 \%$ ) were observed at $100{ }^{\circ} \mathrm{C}$ and diminished at higher reaction temperature. These results indicated that further reaction of dodecane-1-ol did not occurred effectively over Ni$\mathrm{Sn}(1.5) / \mathrm{TiO}_{2}$ catalyst.

\subsubsection{Effect of initial pressure of $\mathrm{H}_{2}$}

The effect of the initial $\mathrm{H}_{2}$ pressure on the dodecanoic acid conversion and product selectivity is shown in Figure 7. The conversion of dodecanoic acid and dodecane-1-ol yield increased, whereas the selectivity of (2), (3), and other products decreased smoothly to almost 0\% between 40-60 bar. The highest yield of dodecane-1-ol (97\%) was achieved at initial pressure $\mathrm{H}_{2}$ of 50-60 bar, suggesting the hydrogenation reaction of dodecanoic acid to dodecane-1-ol over $\mathrm{Ni}-\mathrm{Sn}(1.5) / \mathrm{TiO}_{2}$ catalyst can be proceed effectively under relatively high pressure of $\mathrm{H}_{2}$. These results are consistent with the low $\mathrm{H}_{2}$ uptake of bimetallic $\mathrm{Ni}$ $\mathrm{Sn}(1.5) / \mathrm{TiO}_{2}$.

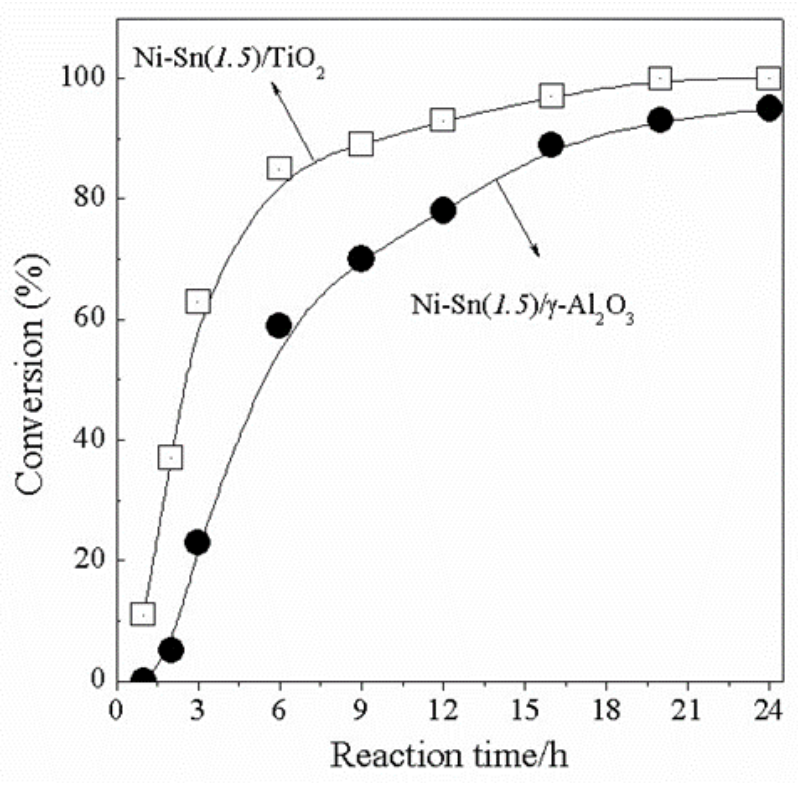

Figure 5. Kinetics of the hydrogenation of dodecanoic acid over bimetallic $\mathrm{Ni}-\mathrm{Sn}(1.5) / \mathrm{TiO}_{2}$ and $\mathrm{Ni}-\mathrm{Sn}(1.5) / \gamma-\mathrm{Al}_{2} \mathrm{O}_{3}$ catalysts. Reaction conditions: Catalyst, $0.065 \mathrm{~g}$; dodecanoic acid, $3.2 \mathrm{mmol}$; iso- $\mathrm{PrOH}, 5 \mathrm{~mL}, 160{ }^{\circ} \mathrm{C} ; \mathrm{H}_{2}$ pressure 30 bar, reaction time is $1-24 \mathrm{~h}$ 


\section{Conclusion}

Selective hydrogenation of dodecanoic acid into dodecane-1-ol over supported bimetallic $\mathrm{Ni}-\mathrm{Sn}$ alloy catalysts is demonstrated. Bimetallic Ni-Sn(1.5)/TiO 2 catalyst was found to be effective for hydrogenation of dodecanoic acid (>99 \% conversion) to dodecane-1-ol (93\% yield) at $160{ }^{\circ} \mathrm{C}, 30 \mathrm{bar} \mathrm{H}_{2}$, and $20 \mathrm{~h}$ and the highest dodecane-1-ol ( $97 \%$ yield) was obtained at initial pressure of $\mathrm{H}_{2} 50$ bar. An increase of reaction temperature slightly enhanced the degree of hydrodeoxygenation of dodecanoic acid to produce dodecane over both $\mathrm{Ni}-\mathrm{Sn}(1.5) / \mathrm{TiO}_{2}$ and $\mathrm{Ni}-\mathrm{Sn}(1.5) / \gamma-\mathrm{Al}_{2} \mathrm{O}_{3}$ catalysts.

\section{Acknowledgments}

These works were financially supported by BPDP-Sawit, Ministry of Finances through GRK-2016 under contract number PRJ49/2016. Partial these works were supported by Insentif Riset Pratama Individu (IRPI) FY 2016-2017 and International Publication Project of DGHE FY 2016 under Grant Number of DIPA-023-04.1.673453/2016 (XRD and ICPAES measurements). We would also like thank to Dr. Husni Wahyu Wijaya for kind assistance in $\mathrm{NH}_{3}$-TPD measurements.

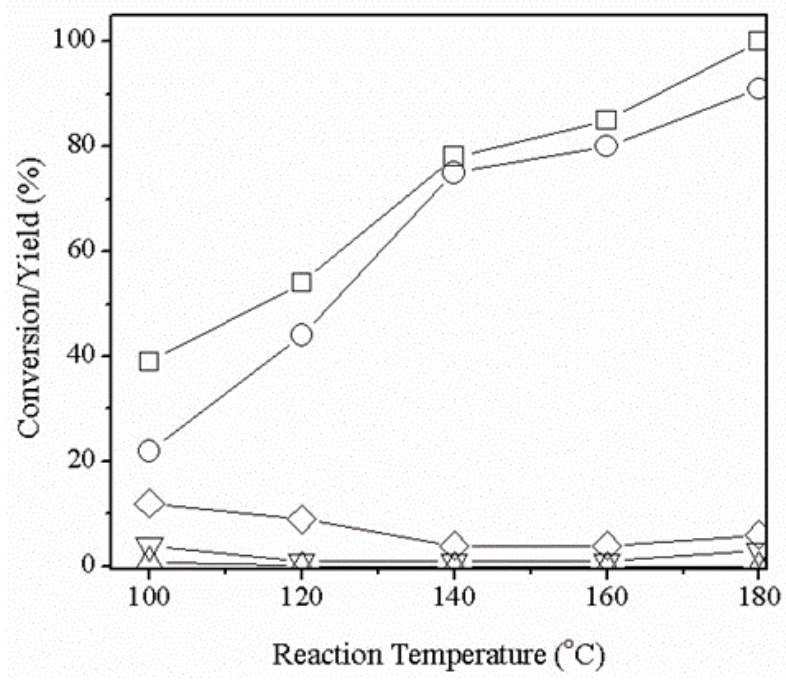

Figure 6. Results of dodecanoic acid hydrogenation over $\mathrm{Ni}-\mathrm{Sn}(1.5) / \mathrm{TiO}_{2}$ at different reaction temperature. Reaction conditions: Catalyst, $0.065 \mathrm{~g}$; dodecanoic acid, $3.2 \mathrm{mmol}$; iso- $\mathrm{PrOH}, 5 \mathrm{~mL}$; reaction temperature, 100-180 ${ }^{\circ} \mathrm{C}$; $\mathrm{H}_{2}$ pressure $30 \mathrm{bar}$; reaction time is $6 \mathrm{~h} .(\square)$ Conversion of dodecanoin acid. (O) Yield of dodecane-1-ol. $(\triangle)$ Yield of dodecane-1,1-diol, and $(\nabla)$ Yield of dodecane. $(\diamond)$ Other products.

\section{References}

[1] Biermann, U., Bornscheuer, U., Meier, M.A.R., Metzger, J.O., Schafer, H.J. (2011). Oils and Fats as Renewable Raw Materials in Chemistry. Angew. Chem., Int. Ed. 50: 38543871.

[2] Turek, T., Trimm, D.L., Cant, N.W. (1994). The Catalytic Hydrogenolysis of Esters to Alcohols. Catal. Rev. Sci. Eng. 36: 645-683.

[3] Adkins, H., Connor, R. (1931). The Catalytic Hydrogenation of Organic Compounds over Copper Chromite. J. Am. Chem. Soc. 53: 1091-1095.

[4] Rozmysłowicz, B., Kirilin, A., Aho, A., Manyar, H.G., Hardacre, C., Warna, J., Salmi, T., Murzin, D.Y. (2015). Selective Hydrogenation of Fatty Acids to Alcohols over Highly Dispersed $\mathrm{ReO}_{x} / \mathrm{TiO}_{2}$ Catalyst. J. Catal. 328: 197-207.

[5] Manyar, H.G., Paun, C., Rilus, R., Rooney, D.W., Thompson, J.M., Hardacre, C. (2010). Highly Selective and Efficient Hydrogenation of Carboxylic Acids to Alcohols using Titania Supported Pt Catalysts. Chem. Commun. 46: 6279-6281.

[6] Gallezot, P., Cerino, P.J., Blanc, B., Flèche, G., Fuertes, P. (1994). Glucose Hydrogenation on Promoted Raney-nickel Catalysts. J. Catal. 46: 93-102.

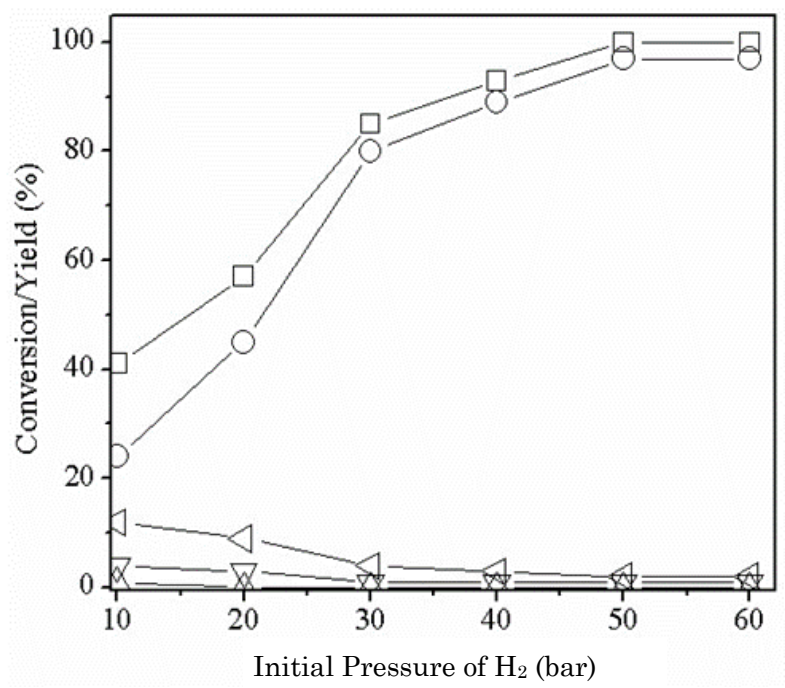

Figure 7. Results of dodecanoic acid hydrogenation over $\mathrm{Ni}-\mathrm{Sn}(1.5) / \mathrm{TiO}_{2}$ at different initial pressure of $\mathrm{H}_{2}$. Reaction conditions: Catalyst, $0.065 \mathrm{~g}$; dodecanoic acid, $3.2 \mathrm{mmol}$; iso- $\mathrm{PrOH}, 5 \mathrm{~mL}, 160{ }^{\circ} \mathrm{C} ; \mathrm{H}_{2}$ pressure $10-50$ bar; reaction time is $6 \mathrm{~h}$. ( $\square$ ) Conversion of dodecanoin acid. (O) Yield of dodecane-1-ol. $(\triangle)$ Yield of dodecane-1,1-diol, and $(\nabla)$ Yield of dodecane. $(\diamond)$ Other products. 
[7] Alonso, D.M., Wettstein, S.G., Dumesic, J.A. (2012). Bimetallic Catalysts for Upgrading of Biomass to Fuels and Chemicals. Chem. Soc. Rev. 41: 8075-8098.

[8] Pritchard, J., Filonenko, G.A., van Putten, R., Hensen, E.J.M., Pidko, E.A. (2015). Heterogeneous and Homogeneous Catalysis for the Hydrogenation of Carboxylic Acid Derivatives: History, Advances and Future Directions, Chem. Soc. Rev. 44: 3808-3833.

[9] Besson, M., Gallezot, P., Pine, C. (2014). Conversion of Biomass into Chemicals over Metal Catalysts. Chem. Rev. 114: 1827-1870.

[10] Huang, C., Zhang, H., Zhao, Y., Chen, S., Liu, Z. (2012). Diatomite-supported Pd-M ( $\mathrm{M}=\mathrm{Cu}$, Co, Ni) Bimetal Nanocatalysts for Selective Hydrogenation of Long-chain Aliphatic Esters. J. Coll. Interface Sci. 386: 60-65.

[11] Shao, Y., Xia, Q., Liu, X., Lu, G., Wang, Y. (2015). $\mathrm{Pd} / \mathrm{Nb}_{2} \mathrm{O}_{5} / \mathrm{SiO}_{2}$ Catalyst for the Direct Hydrodeoxygenation of Biomass-related Compounds to Liquid Alkanes under Mild Conditions. ChemSusChem. 8: 1761-1767.

[12] Miyake, T., Makino, T., Taniguchi, S. I., Watanuki, H., Niki, T., Shimizu, S., Kojima, Y., Sano, M. (2009). Alcohol Synthesis by Hydrogenation of Fatty Acid Methyl Esters on Supported $\mathrm{Ru}-\mathrm{Sn}$ and $\mathrm{Rh}-\mathrm{Sn}$ Catalysts. Appl. Catal. A. 364: 108-112.

[13] Deshpande, V. M., Patterson, W. R., Narasimhan, C. S. (1990). Studies on Ruthenium-tin Boride Catalysts I. Characterization. J. Catal. 121: 165-173.

[14] Deshpande, V.M., Ramnarayan, K., Narasimhan, C.S. (1990). Studies on Ruthenium-tin Boride Catalysts II. Hydrogenation of Fatty Acid Esters to Fatty Alcohols. J. Catal. 21: 174-182.

[15] Rodiansono, R., Hara, T., Ichikuni, N., Shimazu, S. (2012). Highly Efficient and Selective Hydrogenation of Unsaturated Carbonyl Compounds using Ni-Sn Alloy Catalysts. Catal. Sci. Technol. 2: 2139-2145.

[16] Rodiansono, R., Hara, T., Ichikuni, N., Shimazu, S. (2012). A Novel Preparation Method of Ni-Sn Alloy Catalysts Supported on Aluminium Hydroxide: Application to Chemoselective Hydrogenation of Unsaturated Carbonyl Compounds. Catal. Lett. 41(8): 769-771.

[17] Rodiansono, R., Hara, T., Ichikuni, N., Shimazu, S. (2014). Development of Nanoporous Ni-Sn Alloy and Application for Chemoselective Hydrogenation of Furfural to Furfuryl Alcohol. Bull. Chem. React. Eng. Catal. 9(1): 5359
[18] Rodiansono, R., Ghofur, A., Astuti, M.D., Sembiring, K.C. (2015). Catalytic Hydrogenation of Levulinic Acid in Water into $\gamma$ Valerolactone over Bulk Structure of Inexpensive Intermetallic Ni-Sn Alloy Catalysts. Bull. Chem. React. Eng. Catal. 10(2): 192-200.

[19] Rodiansono, R., Astuti, M.D., Hara, T., Ichikuni, N., Shimazu, S. (2016). Efficient Hydrogenation of Levulinic Acid in Water using a Supported Ni-Sn Alloy on Aluminium Hydroxide Catalysts. Catal. Sci. Technol. 6: 2955-2961.

[20] Lowell, S., Shields, J. E., Thomas, M. A., Thommes, M. (2004). Characterization of Porous Solids and Powders: Surface Area, Pore Size and Density, Kluwer Academic Publishers, Netherlands, Chapter 8.

[21] Bartholomew, C.H., Pannel, R.B., Butler, J.L. (1980). Support and Crystallite Size Effects in CO Hydrogenation on Nickel. J. Catal. 65: 335-347.

[22] Bartholomew, C.H., Pannel, R.B. (1980). The Stoichiometry of Hydrogen and Carbon Monoxide Chemisorption on Alumina- and Silicasupported Nickel. J. Catal. 65: 390-401.

[23] Rodiansono, R., Astuti, M.D., Khairi, S., Shimazu, S. (2016). Selective Hydrogenation of Biomass-derived Furfural over Supported $\mathrm{Ni}_{3} \mathrm{Sn}_{2}$ Alloy: Role of Supports. Bull. Chem. React. Eng. Catal. 11(1): 1-9.

[24] Powder Diffraction File, JCPDSInternational Center for Diffraction Data (ICDDS), 1991.

[25] Dumitriu, E., Hulea, V.J. (2003) Effects of Channel Structures and Acid Properties of Large Pore Zeolites in the Liquid Phase Tertbutylation of Phenol. J. Catal. 218: 249-257.

[26] Khandan, N., Kazemeini, M., Aghaziarati, M. (2008). Determining an Optimum Catalyst for Liquid Phase Dehydration of Methanol to Dimethyl Ether. J. Appl. Catal. A.349: 6-12.

[27] Dandekar, A., Vannice, M.A. (1999). Crotonaldehyde Hydrogenation on $\mathrm{Pt}_{/} \mathrm{TiO}_{2}$ and Ni/TiO ${ }_{2}$ SMSI Catalysts. J. Catal. 183: 344354.

[28] Sordelli, L., Psaro, R., Vlaic, G., Cepparo, A., Recchia, S., Fusi, A., Zanoni, R. (1999). EXAFS Studies of Supported Rh-Sn Catalysts for Citral Hydrogenation. J. Catal. 182: 186-198.

[29] Margitfalvi, J. L., Tompos, A., Kolosova, I., Valyon, J. (1998). Reaction Induced Selectivity Improvement in the Hydrogenation of Crotonaldehyde over $\mathrm{Sn}-\mathrm{Pt} / \mathrm{SiO}_{2}$ Catalysts. J. Catal. 174: 246-249. 